\title{
THE ROLE OF CIGARETTE SMOKING AND ALCOHOL CONSUMPTION IN PULMONARY TUBERCULOSIS DEVELOPMENT AND RECURRENCE
}

\author{
Marina Lampalo ${ }^{1}$, Irena Jukić ${ }^{2}$ Jasna Bingulac-Popović ${ }^{3}$, Hana Safić Stanić², \\ Blaženka Barišić ${ }^{1}$ and Sanja Popović-Grle
}

${ }^{1}$ Jordanovac University Department for Lung Diseases, Zagreb University Hospital Centre, Zagreb, Croatia;

${ }^{2}$ Croatian Institute of Transfusion Medicine, Zagreb, Croatia; School of Medicine, Josip Juraj Strossmayer University of Osijek, Osijek, Croatia;

${ }^{3}$ Department of Molecular Diagnosis, Croatian Institute of Transfusion Medicine, Zagreb, Croatia

SUMMARY - During a two-year period (2001-2003), 464 patients were treated for tuberculosis at Jordanovac Department for Lung Diseases in Croatia. Besides pulmonary tuberculosis in $97.7 \%$ of patients, patients were also treated for tuberculous pleurisy $(0.9 \%)$, tuberculous laryngitis $(0.6 \%)$, tuberculous meningitis $(0.2 \%)$, tuberculous pericarditis $(0.2 \%)$ and urogenital tuberculosis $(0.4 \%)$. Out of the total number of patients, $57.3 \%$ declared themselves to be active smokers (men were predominant and made up to $80.8 \%$ ) and $20.9 \%$ to be active alcohol consumers. Both risk factors, i.e. smoking and alcohol consumption, were present in $15.1 \%$ of all patients. The most common comorbidities were diabetes mellitus (30.4\%), cardiac diseases (11.2\%) and chronic obstructive pulmonary disease (8.0\%). Lung carcinoma was the most common malignant disease ( $\mathrm{n}=51$ ), with Mycobacterium tuberculosis isolated in 33\% of them. Seventy-two of $464(15.5 \%)$ patients had recurrences of tuberculosis. Of these, $30.5 \%$ had one of the risk factors ( $20.8 \%$ were smokers and $9.7 \%$ consumed alcohol), while $32.5 \%$ of patients had both risk factors. In conclusion, cigarette smoking was proved to be the most significant risk factor for development of pulmonary tuberculosis and its recurrence.

Key words: Tuberculosis; Cigarette smoking; Alcoholism; Mycobacterium tuberculosis; Croatia

\section{Introduction}

Tuberculosis is an infectious disease caused by the Mycobacterium (M.) tuberculosis bacillus. It may involve any organ in the human body, but most commonly affects the lungs ( $80 \%-90 \%$ of cases) $)^{1}$. Tuberculosis is a major public health problem worldwide, and one of the top 10 causes of death worldwide, being the leading cause of death among infectious diseases. According to the latest World Health Organization data, in 2016, 10.4 million people were infected with tubercu-

Correspondence to: Marina Lampalo, PhD, Zagreb University Hospital Centre, Jordanovac University Department for Lung Diseases, Jordanovac 104, HR-10000 Zagreb, Croatia

E-mail: marina.lampalo@gmail.com

Received September 13, 2018, accepted October 1, 2018 losis and 1.3 million people died during the same year ${ }^{2}$. One-quarter of the entire world population are infected with tuberculosis bacillus ${ }^{3}$. In 2016, the highest number of patients diagnosed with tuberculosis was recorded in Asia, followed by African countries. Nearly three million people infected with tuberculosis have no clear diagnosis and as such remain untreated ${ }^{3,4}$.

In 2016, a tuberculosis incidence of 12/100,000 inhabitants was recorded in Croatia, which makes a medium high rate 5 . Many socioeconomic factors such as malnutrition, alcohol abuse and cigarette smoking have been recognized as risk factors for the development and emergence of active tuberculosis recurrence ${ }^{6}$.

The aim of our study was to determine the correlation of cigarette smoking and alcohol consumption with the incidence and severity of tuberculosis recur- 
rence, and to identify which comorbidity is most commonly present in tuberculosis patients.

\section{Patients and Methods}

This study was conducted among patients treated for tuberculosis at Jordanovac Department for Lung Diseases during the 2001-2003 period. Analyzing patient history, we collected data on age, sex, habits, comorbidity and clinical manifestations of tuberculosis (pulmonary/extrapulmonary), followed by the number of tuberculosis recurrences. In the microbiological laboratory registry, we found data on the number of directly positive and negative microbiological samples, type of microbiological samples, as well as on drug susceptibility testing. The study included 464 patients treated over two years, with the highest number of patients in 2003, when 230 patients were treated for tuberculosis; all clinical and microbiological indicators were analyzed in separate. The study was approved by the Ethics Committee of the Jordanovac Department for Lung Diseases.

\section{Results}

Demographic characteristics of 464 tuberculosis patients during the two-year follow-up are presented in Table 1 . In that period, pulmonary tuberculosis was detected in $97.7 \%$ and extrapulmonary tuberculosis in $2.3 \%$ of the patients. Additionally, 72 (15.5\%) patients experienced recurrence of the disease. Out of all patients with recurrence, $32.5 \%$ were tobacco and alcohol consumers, $20.8 \%$ were tobacco consumers only, $9.7 \%$ exclusively consumed alcohol, while $37.0 \%$ did not consume alcohol or tobacco (Table 2). Out of the total number of tuberculosis patients, $20.9 \%$ consumed alcohol, $57.3 \%$ were active tobacco smokers and $11.0 \%$ had ceased smoking just before or during the disease. In the active tobacco smokers, the smoking severity index expressed in pack-years was 41.5 for men and 25.2 for women.

When tuberculosis patients were analyzed in a one-year period, 230 patients treated for tuberculosis in 2003 showed a similar sex distribution, with 143 (62.1\%) men and 87 (37.9\%) women. The largest number of patients in this period was in the 40-60 age group. Pulmonary tuberculosis was diagnosed in $95.2 \%$ of patients, while $16.9 \%$ of patients had extrapulmo-
Table 1. Demographic characteristics of tuberculosis patients (sex, age and smoking severity index)

\begin{tabular}{|l|l|l|}
\hline Patient characteristic & $\mathrm{N}=464$ & $\%$ \\
\hline $\begin{array}{l}\text { Sex: } \\
\quad \text { male, } \mathrm{n}\end{array}$ & 291 & 62.7 \\
female, $\mathrm{n}$ & 173 & 37.3 \\
\hline Age median (yrs): & & \\
$\quad$ male & 52.6 & \\
$\quad$ female & 58.3 & \\
\hline Smoking severity index: & & \\
$\quad$ male & 41.5 & \\
female & 25.2 & \\
\hline
\end{tabular}

Table 2. Risk factors among patients with tuberculosis recurrence

\begin{tabular}{|l|l|l|}
\hline Risk factor & $\begin{array}{l}\mathrm{N}=72^{*} \\
\mathrm{n}\end{array}$ & $\%$ \\
\hline Cigarette smoking & 15 & 20.8 \\
$\begin{array}{l}\text { Alcohol consumption } \\
\text { Cigarette smoking and alcohol } \\
\text { consumption }\end{array}$ & 7 & 9.7 \\
None & 23 & 32.5 \\
\hline
\end{tabular}

*Total number of patients with tuberculosis recurrence: $\mathrm{N}=72$ ( $15.5 \%$ of 464 patients)

nary form of tuberculosis, in combination with the pulmonary form. The most common extrapulmonary form was specific pleuritis in $11.7 \%(n=27)$, followed by specific lymphadenitis in $3 \%(n=7)$, miliary form of tuberculosis in $1.3 \%(n=3)$ and kidney tuberculosis in $0.86 \%(n=2)$ of patients. Only one $(0.43 \%)$ patient had laryngeal tuberculosis. Out of the total number of patients, $26.3 \%$ had recurrence and $73.5 \%$ were directly positive. Comorbidities were present in $63.8 \%$ of patients, most commonly diabetes and chronic obstructive pulmonary disease, which accounted for $12.2 \%$ of patients, followed by malignancies with $6.5 \%$. Lung cancer was the most common malignant disease. $M$. tuberculosis was isolated in $33 \%$ of the total number of lung cancer patients $(n=51)$. Cigarette smoking was present in $51.3 \%$ and alcoholism in $36.5 \%$ of patients. In $73.5 \%$ of patients, tuberculosis was diagnosed directly by microscopy in sputum, catheter aspirate, tumor tissue, lymph node and wound smear. Resistance to one or more antituberculotic drugs was demonstrated by resistance test in ten (4.3\%) patients, while 
multi-drug resistant tuberculosis was found in four (1.7\%) patients.

\section{Discussion}

Despite the progress in modern medicine, tuberculosis is still a major clinical problem worldwide. One of the most relevant risk factors, as demonstrated in our study, was cigarette smoking, with $57.3 \%$ of tuberculosis patients reported as active smokers, while $11 \%$ of patients had ceased smoking just before or during the disease. Alcoholism as a risk factor for tuberculosis recurrence was verified in $20.9 \%$ of tuberculosis patients. The results are shown for a two-year period during which tuberculosis patients were monitored. If tuberculosis patients could have been analyzed over a oneyear period, $51.3 \%$ of those respondents would be cigarette smokers and even $36.5 \%$ of them alcohol consumers. Given the results obtained in our study, it is considered that smokers, compared to non-smokers (one-third of cases), have an almost twofold risk of $M$. tuberculosis infection and development of the active form of the disease.

More than 20\% of tuberculosis prevalence globally is associated with smoking, and cigarette smoking increases the risk of developing tuberculosis by almost two and a half times ${ }^{7}$. It has been shown that affected patients, at the same time smokers, have more frequent disorders such as cough and dyspnea, radiologic bronchodynamic dissemination and caverns, and miliary tuberculosis as the hematogenic form of the disease. Given the great importance of tuberculosis and cigarette smoking association, there are numerous studies that have studied this topic. The available data are also contradictory as some studies suggest that smoking cessation has a positive effect on the control of the disease itself, whereas others indicate that former smokers have weak immune response at the alveolar macrophage level ${ }^{8}$. Some studies indicate that cigarette smoke prevents specific growth and activation of CD4+ T cells and lowers CD4+ and CD8+ T cell levels. Other smoking induced mechanisms include oxidative stress due to infection and disturbances in the function of tracheobronchial cilia ${ }^{9}$. More data on this topic were obtained by research on mice exposed to cigarette smoke and then infected with $M$. tuberculosis. Cigarette smoke exposure amplified the effect of bacteria in the infected mice and directly inhibited the response of lung $\mathrm{T}$ cells to the presence of $M$. tuberculosis in the relevant animal model ${ }^{10}$.

Our hypothesis was also confirmed by a major study on 5567 Taiwan tuberculosis patients, which demonstrated the impact of cigarette smoking on tuberculosis development. Active smokers were twice as likely to develop recurrent tuberculosis compared to former smokers and individuals who had never consumed tobacco products ${ }^{11}$. Another analytical study from Iran showed that $72 \%$ of patients infected with $M$. tuberculosis were active smokers. Smoking cessation as a form of intervention resulted in $11 \%$ reduction of the mentioned rate at the time of the next visit. This figure was reduced to only $2 \%$ several months after treatment ${ }^{12}$. Nearly 1.1 million respondents in India participated in the study conducted in 2008, which established that tuberculosis mortality rate was 1.7 times higher in smokers compared to non-smokers ${ }^{13}$. In 2009, a group of scientists reported an increased risk of mortality by $60 \%$ in more than a million South Korean smokers suffering from tuberculosis ${ }^{14}$. Another major study in Cambodia revealed that the tuberculosis diagnosis was more common in men who consumed tobacco products $^{15}$. The data from many meta-studies from other countries and the latest global assessment support the fact that the global reduction in tuberculosis infection is highly dependent on successful smoking control ${ }^{15}$.

On the other hand, the study of Gandhy et al. among Wistar rats showed that some nicotine analogs had anti-mycobacterial effect after oral and parenteral administration, believing that nicotine was responsible for $M$. tuberculosis destruction ${ }^{16}$. The question is why there is a high correlation between smoking and prevalence of tuberculosis, as stated above. The most likely theory is the possibility that nicotine inhibits the production of TNF $\alpha$ necrosis factor in pulmonary macrophages, and thus the patient becomes more susceptible to development of progressive latent infection ${ }^{17}$. The effect of cigarette smoking in patients of different age groups was analyzed and compared with the incidence of latent tuberculosis ${ }^{18}$. Older patients were more susceptible to the negative effect of smoking and development of latent disease form. The likelihood ratio was significantly higher in older patients than in younger ones, and the greatest risk was observed in patients aged 56-74, declining slowly after the age of $75^{18}$.

Some studies showed that nicotine decreased macrophage ability to destroy $M$. tuberculosis bacteria. An- 
alyzing the macrophage response to the presence of tuberculosis infection, O'Leary et al. compared functional impairment seen in human alveolar macrophages from nonsmokers, smokers, and ex-smokers ${ }^{19}$. They observed an inadequate cytokine response to infection in smokers and skewing the inflammatory mediator profile of macrophages in the lung, which may have affected host susceptibility to the disease ${ }^{19}$. Bai et al. showed that exposure to nicotine impaired the macrophage anti- $M t b$ defense by inhibition of autophagy via binding to nicotinic acetylcholine receptor and activation of immunosuppressive Treg cells ${ }^{20}$. Their next study showed that passive smokers also had an increased risk of developing latent and active tuberculosis. This susceptibility may be due to the increased exposure to the tubercle bacilli from the increased cough seen in smokers, along with suppressed anti-tuberculosis immunity, enhanced activity of immunosuppressive N2 neutrophils or Tregs, or a combination of these factors ${ }^{21}$. Gleeson et al. report on human alveolar macrophages in smokers to be attenuated significantly, with consequent impairment of the glycolytic response to $M$. tuberculosis infection, which is crucial in the early host immune response to the pathogen ${ }^{22}$.

The combination of tuberculosis and alcoholism, which many consider as the most widespread disease of mankind, represents a medical, social and epidemiological problem. The reduced host resistance to the infection is due to the specific lifestyle of alcoholics. Mortality among alcohol consuming tuberculosis patients is significantly higher compared with mortality of other infected individuals. Affected alcoholics are a significant social and epidemiological problem because they often move among large groups of people such as waiting rooms and restaurants ${ }^{23,24}$. A recently published study on a mouse model to determine the effects of chronic alcohol consumption on immune responses during $M$. tuberculosis infection demonstrated that alcohol enhanced IFN- $\alpha$ production by CD11b+Ly6G+ cells in the lungs of young Mtb-infected mice, which led to macrophage necroptosis and increased mortality. Their findings also suggest that young alcoholic individuals with latent tuberculosis have a higher risk of developing active tuberculosis infection ${ }^{25}$. The prevalence of alcoholism among patients with tuberculosis is $8 \%-10 \%$, and there is a significantly higher incidence of tuberculosis recurrence among alcoholics. The results of our study revealed even $20.9 \%$ of tuberculosis patients to be active alcohol consumers and even 15.1\% of patients with a combination of cigarette smoking and alcohol.

In conclusion, cigarette smoking proved to be the most important risk factor for pulmonary tuberculosis disease found in $57.3 \%$ of patients, and $11.0 \%$ of patients had ceased smoking just before or during the disease. Alcoholism as a risk factor for tuberculosis was demonstrated in $20.9 \%$ of patients. In addition, the largest number of patients with tuberculosis recurrence was from the smoker group (21\%), followed by alcohol consumers (10\%). Both risk factors, smoking and alcohol consumption, accounted for $32.5 \%$ of patients with recurrent disease. The most common comorbidities in patients with tuberculosis were chronic obstructive pulmonary disease, diabetes mellitus, cardiovascular disease and malignancies.

\section{References}

1. Dolin PJ, Ravilgione MC, Kochi A. Global tuberculosis incidence and mortality during 1990-2000. Bull World Health Org. 1994;72(2):213-20

2. Global Tuberculosis WHO Report 2017. Available from: http: //www.who.int/tb/publications/global_report/en/ (accessed Dec 28, 2017).

3. WHO Fact Sheet No. 104: Tuberculosis global facts. Available from: http://www.who.int/tb/publications/factsheet_global. pdf?ua=1 (accessed Dec 28, 2017).

4. Sulis G, Roggi A, Matteelli A, Raviglione MC. Tuberculosis: epidemiology and control. Mediterr J Hematol Infect Dis. 2014;6(1):e2014070. doi: 10.4084/MJHID.2014.070

5. Incidence of Tuberculosis (per 100,000 People). World Health Organization, Global Tuberculosis Report. Available from: https://data.worldbank.org/indicator/SH.TBS.INCD (accessed Dec 28, 2017).

6. Narasimhan P, Wood J, Macintyre CR, Mathai D. Risk factors for tuberculosis. Pulm Med. 2013;2013:828939. doi: $10.1155 / 2013 / 828939$

7. Basu S, Stuckler D, Bitton A, Glantz SA. Projected effects of tobacco smoking on worldwide tuberculosis control: mathematical modelling analysis. BMJ. 2011;343:d5506. doi: 10.1136/bmj.d5506

8. Altet N, Latorre I, Jiménez-Fuentes MÁ, Maldonado J, Molina I, González-Díaz Y, et al. Assessment of the influence of direct tobacco smoke on infection and active TB management. PLoS One. 2017;12(8): e0182998. doi: 10.1371/journal. pone.0182998

9. Van Zyl Smit RN, Pai M, Yew WW, Leung CC, Zumla A, Bateman ED, et al. Global lung health: the colliding epidemics 
of tuberculosis, tobacco smoking, HIV and COPD. Eur Respir J. 2010;35(1):27-33. doi: 10.1183/09031936.00072909

10. Feng Y, Kong Y, Barnes PF, Huang FF, Klucar P, Wang X, et al. Exposure to cigarette smoke inhibits the pulmonary T-cell response to influenza virus and Mycobacterium tuberculosis. Infect Immun. 2011;79(1):229-37. doi: 10.1128/IAI.00709-10

11. Yen YF, Yen MY, Lin YS, Lin YP, Shih HC, Li LH, et al. Smoking increases risk of recurrence after successful anti-tuberculosis treatment: a population-based study. Int J Tuberc Lung Dis. 2014;18:492-8. doi: 10.5588/ijtld.13.0694

12. Safa M, Tabarsi P, Sharifi H. Pattern of tobacco consumption among TB patients in a tuberculosis referral center. Tanaffos. 2011;10(2):50-5.

13. Jha P, Jacob B, Gajalakshmi V, Gupta PC, Dhingra N, Kumar $\mathrm{R}$, et al. A nationally representative case-control study of smoking and death in India. N Engl J Med. 2008;358(11):1137-47. doi: 10.1056/NEJMsa0707719

14. Saad T, Tirkey AS. Is smoking a modifiable risk factor for developing pulmonary tuberculosis. IOSR Journal of Dental and Medical Sciences. 2014;13(1):47-53. doi: 10.9790/085313184753

15. Singh PN, Yel D, Kheam T, Hurd G, Job JS. Cigarette smoking and tuberculosis in Cambodia: findings from a national sample. Tob Induc Dis. 2013;11(1):8. doi: 10.1186/1617-9625-11-8

16. Gandhi PT, Athmaram TN, Arunkumar GR. Novel nicotine analogues with potential anti-mycobacterial activity. Bioorg Med Chem. 2016;15;24(8):1637-47. doi: 10.1016/j.bmc. 2016.02.035

17. Davies PD, Yew WW, Ganguly D, Davidow AL, Reichman LB, Dheda K, et al. Smoking and tuberculosis: the epidemiological association and immunopathogenesis. Trans R Soc Trop Med Hyg. 2006;100(4):291-8. doi: 10.1016/j.trstmh.2005.06.034
18. Feng JY, Huang SF, Ting WY, Lee MC, Chen YC, Lin YY, et al. Impact of cigarette smoking on latent tuberculosis infection: does age matter? Eur Respir J. 2014;43(2):630-2. doi: 10.1183/09031936.00118313

19. O'Leary SM, Coleman MM, Chew WM, Morrow C, McLaughlin AM, Gleeson LE, et al. Cigarette smoking impairs human pulmonary immunity to Mycobacterium tuberculosis. Am J Respir Crit Care Med. 2014;190(12):1430-6. doi: 10.1164/rccm.201407-1385OC

20. Bai X, Stitzel JA, Bai A, Zambrano CA, Phillips M, Marrack P, Chan ED. Nicotine impairs macrophage control of Mycobacterium tuberculosis. Am J Respir Cell Mol Biol. 2017;57(3): 324-33. doi: 10.1165/rcmb.2016-0270OC

21. Bai X, Aerts SL, Verma D, Ordway DJ, Chan ED. Epidemiologic evidence of and potential mechanisms by which secondhand smoke causes predisposition to latent and active tuberculosis. Immune Netw. 2018;18(3):e22. doi:10.4110/in.2018.18.e22

22. Gleeson LE, Ryan D, O'Leary SM, McLaughlin AM, Sheedy FJ, Keane JM. Cigarette smoking impairs the bioenergetic immune response to Mycobacterium tuberculosis infection. Am J Respir Cell Mol Biol. 2018 Nov;59(5):572-9. doi: 10.1165/ rcmb.2018-0162OC.

23. Grange J, Story A, Zumla A. Tuberculosis in disadvantaged groups. Curr Opin Pulm Med. 2001;7:160-4.

24. Inderlied CB, Salfinger M. Antimicrobial agents and susceptibility tests: Mycobacteria. In: Murray PR, Baron EJ, Pfaller MA, Tenover FC, Yolken RH, editors. Manual of Clinical Microbiology. $6^{\text {th }}$ edn. Washington, D.C.: ASM Press; 1995. p. 1385-404.

25. Tripathi D, Welch E, Cheekatla SS, Radhakrishnan RK, Venkatasubramanian S, Paidipally $\mathrm{P}$, et al. Alcohol enhances type 1 interferon- $\alpha$ production and mortality in young mice infected with Mycobacterium tuberculosis. PLoS Pathog. 2018;14(8): e1007174. doi: 10.1371/journal.ppat.1007174

\section{Sažetak}

\section{ULOGA PUŠENJA I UZIMANJA ALKOHOLNIH PIĆA U RAZVOJU I PONAVLJANJU PLUĆNE TUBERKULOZE}

\section{Lampalo, I. Jukić, J. Bingulac-Popović, H. Safić Stanić, B. Barišić i S. Popović-Grle}

Tijekom dvije godine (2001.-2003.) u Klinici za plućne bolesti “Jordanovac”, Zagreb, Hrvatska, od tuberkuloze je liječeno 464 bolesnika. Osim najčešće plućne tuberkuloze u 97,7\% bolesnika, oboljeli su liječeni i od eksudativnog tuberkuloznog pleuritisa $(0,9 \%)$, laringealne tuberkuloze $(0,6 \%)$, tuberkuloznog meningitisa $(0,2 \%)$, perikardijalne tuberkuloze $(0,2 \%)$ te tuberkuloze koja je zahvatila urogenitalni sustav $(0,4 \%)$. Od ukupnog broja bolesnika $57,3 \%$ ih se izjasnilo kao aktivni pušači (muškarci 80,8\%), dok je 20,9\% deklarirano kao aktivni konzumenti alkohola. Ukupno je 15,1\% bolesnika imalo oba rizična čimbenika u anamnezi, tj. i aktivno pušenje cigareta i konzumaciju alkohola. Od komorbiditeta najčešća je bila šećerna bolest u 30,4\% bolesnika, od srčanih bolesti bolovalo je 11,2\% bolesnika, dok je kronična opstruktivna plućna bolest bila prisutna u $8 \%$ bolesnika. Karcinom pluća bio je najčešće zastupljen među malignim bolestima. Od ukupnog broja oboljelih od karcinoma pluća (51 bolesnik), Mycobacterium tuberculosis izolirali smo u 33\% bolesnika. Recidivi tuberkuloze su zabilježeni u 72 (15,5\%) bolesnika. Jedan rizični čimbenik imalo je 30,5\% bolesnika: pušača je bilo 20,8\%, dok je alkohol konzumiralo $9,7 \%$ bolesnika, a 32,5\% bolesnika imali su oba rizična čimbenika. Zaključno, pušenje cigareta pokazalo se kao najznačajniji rizični čimbenik za razvoj plućne tuberkuloze, kao i za pojavu recidiva tuberkuloze.

Ključne riječi: Tuberkuloza; Cigarete, pušenje; Alkoholizam; Mycobacterium tuberculosis; Hrvatska 